2011

\title{
Regulating Social Media Use in the Workplace
}

Yemisi Dina

Osgoode Hall Law School of York University, ydina@osgoode.yorku.ca

Follow this and additional works at: https://digitalcommons.osgoode.yorku.ca/public_writing

Part of the Law Commons, and the Law Librarianship Commons

\section{Recommended Citation}

Dina, Yemisi, "Regulating Social Media Use in the Workplace" (2011). Editorials and Commentaries. 178.

https://digitalcommons.osgoode.yorku.ca/public_writing/178

This Response or Comment is brought to you for free and open access by the Faculty Scholarship at Osgoode Digital Commons. It has been accepted for inclusion in Editorials and Commentaries by an authorized administrator of Osgoode Digital Commons. 


\section{INTRODUCTION}

The Internet has created various empowerment and communication tools. No one would have envisaged that the Internet will be so powerful with advanced tools emerging sporadically for users. The advent of social networking sites (SNS) has become a reality of the digital age. These sites are highly interactive, creative and addictive. Statistics compiled by TNS Canadian Facts showed that six in ten people in their 30s have visited at least one SNS while $45 \%$ of those in their 40s have also done so. ${ }^{1}$ Also figures from TNS show that teens and young adults are the heaviest users of these sites with $83 \%$ of $13-17$ year olds and $74 \%$ of $18-29$ year olds visiting at least one the sites before. ${ }^{2}$ These sites have millions of users registered and visiting them on a daily basis.

Social networking websites like Facebook, You Tube, LinkedIn, Twitter were designed to help interested parties share and connect with themselves. Facebook remains the most popular of the social networking sites in the world today with 500 million active users worldwide. Its users spend over 700 billion minutes per month on it $^{3}$. Users of social networking sites post comments, pictures and personal information on these medium thereby eliminating any amount of distance whatsoever. Social networking sites have successfully instituted not just connections but also a lot of changes in the digital world. SNS provide a great opportunity for individuals to exchange and reach out on personal, professional and social ideas but its use has also been the subject of litigation in the courts lately just like any man made invention.

\footnotetext{
${ }^{1}$ Canada, (2009, May 21). Social Networks Sites in the Workplace: An Introduction. Retrieved April 16, 2011, from Office of the Privacy Commissioner of Canada: http://www.priv.gc.ca/fs-fi/02_05_d_40_sn_e.cfm\#contenttop

${ }^{2}$ Op Cit

${ }^{3}$ Facebook. (2011). Press Room. Retrieved May 10, 2011, from facebook: http://www.facebook.com/press/info.php?statistics
} 


\section{facebook - Linked in}

People using these sites have sparked a number of legal challenges that have dramatically changed the world. Users have been fired for postings they created on Facebook, You Tube or Twitter. These developments raise a number of questions as to whether there are any guidelines on the use of these tools by employers for employees. Should employers and regulatory bodies have policies and guidelines in place in the workplace for using these tools? I have decided to review one of the very first cases in Canada where employees in a unionized environment were fired for the postings they made on Facebook. This issue is relatively new and emerging as I noted in my introductory paragraph but is is very crucial and important and needs to be addressed eventhough many employers are avoiding dealing with it.

This commentary is a review of the recently decided case - Lougheed Imports Ltd. Operating West Coast Mazda doing business as West Coast Detail \& Accessory Centre v United Food and Commercial Workers International Union, Local 1518. The case involved two employees in a unionized environment who were fired for their "egregious" postings on Facebook which makes it the one of the first cases where employers took this kind of action in Canada. The Union filed a complaint before the British Columbia Labour Relations Board alleging that the employer was in breach of sections 5, 6 and 9 of the Labour Relations Code. Another significance of this case is that it highlights the impact of the use of information technology through social media as a means of communication in the work place; whereas not too long ago the common practice was that this kind of information was in the form of print using bulletin boards. 
I note in this review that the British Columbia Labour Relations Board in this case overlooked the crucial aspect of employers setting workplace policies and expectations regarding the use of social media despite the fact that the employer in this instance admitted that they did not have any experience with issues arising from Facebook postings. Having policies in place in the workplace becomes imperative because of the technological advancements which has seen a proliferation of social networking sites taking over all areas of our lives and are being relied upon as a means of communication. These policies will help to clarify employer's expectations on the use of social media by employees in the workplace and outside. In the case of regulated professions, it is also necessary to have policies and guidelines by regulatory bodies; an initiative that is being taking seriously by some institutions. Labour unions also need to take similar proactive steps by having social media policies in contract agreements. In other words, the policies will state in clear terms the employers' expectations when employees are using social media and they will act accordingly. Such policies will be cognizant of the provisions of the Canadian Charter of Rights and Freedom regarding the freedom of expression. In the current case, I strongly believe that it would have been a different matter had the employers (Lougheed Imports Ltd) had guidelines and policies on the use of social media in place, then the employees involved in this case would not have gone so far with the kind of postings they made on their Facebook pages about their supervisors and their employer.

In reviewing this case, I have read some other cases (some of which I cited in my analysis) in the same context but it seems that many employers are shying away from setting guidelines and policy. Just like many institutions and employers have computer use guidelines, it is highly necessary to have a similar one for the use of social media. Employees need to know and understand what is required of them when using social media whether during work hours or 
after work hours. Some employers have tried to address this by restricting access to websites through firewalls on their companies' network; but this still does not address the problem in the days of android technology and mobile devices.

The case review begins by setting out some of the facts in the case and ends by arguing that it is important for employers and regulatory agencies to prescribe clear guidelines as to what they expect when employees and their members are using social networking sites. The commentary outlines and critically evaluates the arguments that were advanced by the Union in support of unfair labour practices. In February 2011, the Ontario College of Teachers became one of the first regulatory bodies in Canada to come up with a formal guideline and policy on the use of electronic communication and social media for its members. I have also included my analysis of this guideline in my case review to justify the significance of this initiative.

The two main issues raised in this case are:

1. Whether the employer committed unfair labour practices as prescribed by sections 5,6 and 9 of the British Columbia Labour Relations Code;

2. Whether the two employees that were fired were exercising their freedom of expression rights available to them by the provisions of section 2(b) of the Canadian Charter of Rights and Freedoms through social media postings on Facebook.

\section{Case Summary}

Because of the offensive nature of the language that was used by the parties in this case, the names are not mentioned in the transcript, their initials have been used. J. T. was employed as a detailer at the West Coast Mazda in Pitt Meadows, British Columbia for about 4 years. A. P. was employed as an installer at this same company and has been with them for about 2 years. F. 
Y. is the reconditioning manager and has been in that position for about four and a half years. J.T. reported directly to J.T. while A.P reported to another manager but took instructions from him.

On August 26, 2010, the Union applied for certification of a bargaining unit of "employees at and from 19120 Lougheed Highway, Pitt Meadows, BC, except sales, office employees and glass installers". The Board sent the Employer notice of the application on August 27, 2010. The Union received certification on September 8, 2010. Dates are extremely critical in this case due to the nature of the incidents and Facebook postings.

The Employer knew about J. T.'s support for the Union as he was one of the key organizers during the organizing campaign. A. P. was also a supporter and this became aware to the Employer on August 27.

J.T, F.Y. and A.P. were all friends on Facebook, being "friends" on this social networking sites implies that they can see each other's information and postings on this website. J.T. had almost 100 friends while A.P. had 377 friends which include present and former employees of the West Coast Mazda detailing and accessory shop. A. P. according to the facts of the case deleted his account on October 1, 2010.

F. Y. is able to access his Facebook account on his cell phone and he checks his account every day. On August 27, 2010, he checked his account and the newsfeed showed the following comment on J.T's status:

Sometimes ya have good smooth days, when nobodys fucking with your ability to earn a living..... and sometimes accidents DO happen, its unfortunate, but that's why there called accidents right? ${ }^{4}$ Again on September 8, 2010, J. T. posted another comment on his page:

\footnotetext{
${ }^{4}$ Lougheed Imports Ltd. Operating West Coast Mazda doing business as West Coast Detail \& Accessory Centre v United Food and Commercial Workers International Union, Local 15182010 CanLII 62482 (BC L.R.B.). p. 3.
} 
When a labour relations lawyer calls ya at 7PM and ya fax him 25 task sheets, ya gotta wonder??? Unfair labour practices, coupled with workplace harassment... C'mon Guys??? At least read up on the laws before ya throw the first punch... because that second punch can by a DOOZY....

J.T. made the following posting on his status page on September 17, 2010:

If somebody mentally attacks you, and you stab him in the face 14 or 16 times....that constitutes self defence doesn't it????

Following this F.Y. saw the following conversation between J.T. and a non-work related friend:

.... Works been a shit-storm lately, our shop is a certified union now, so been stressed $r t$ out (Management needs somebody to blame \& Im that guy).... so yeah if you see summa my ANGRY statuses lately, that's why....

J.T. also wrote on his status the "stress relief anyone" and included the top five kills from Dexter - a television show about a vigilante killer.

Upon seeing the first posting of August 27, F.Y. shared this with J.C. - Fixed Operations Manager at West Coast Mazda. He also stated that he was a little bit threatened by the second posting of September 8 which he also shared with J.C. J.C. told F.Y. that he was unsure about what to do.

On September 17, F.Y. was told by one of his friends who was a former employee at West Coast Mazda that J.T. had removed F.Y. as a friend on his (J.T.) Facebook page which means that he no longer had access. J.C. then asked this friend to keep him informed about developments on J. T's page and this friend subsequently allowed J. C. to log on to his account where J.C. was able to print out the postings on J.T's Facebook page.

On September 23, there was meeting in the office with a representative from WorkSafe B.C., J.C., F.Y., another manager, Marco, A.P. and two other employees. J.T. was said to have stormed into the meeting, agitated and saying that he should have been part of the meeting; but he was asked to return to his duties by J.C. After the meeting J.T. was issued a written warning about his "disruptive, interruptive and confrontational behaviour" when management was 
meeting with the representative of WorkSafe BC. The letter further stated that any further behaviour like the one described will "lead to termination of employment". At this stage nothing had been said to J.T. about the Facebook postings.

Meanwhile on September 23, 24 and 27 respectively, J.T. made the following postings as his status update and these postings were viewed by J.C. using the former employee's Facebook account:

Completely Exploded \& SNAPPED on the Fixed Ops/Head Prick at work today....He sent me Home (With Pay) and wrote me up (Strike 1)....although the FUKN gloves are off now,,,I gotta control my temper. One strike in 4 years aint bad, I guess (September 23)

Hhhmmmm??? According to this reprimand at work, Im confrontational \& disruptive to the WHOLE shop ... AND .... My outburst yesterday was threatening and didn't allow The WestCoastAutoGroup to conduct regular business.... well????All I Gotta say is they pissed off the WRONG GUY ....big time. (September 24)

A safety meeting took place at the shop on September 28 to update them about the meeting with WorkSafe BC. According to the facts of the case the meeting went well but at the end of the meeting, J.C. asked J.T. some follow up questions and his response was described as "loud".

J.T. on September 28 made the following postings on his Facebook page:

Was asked for my opinions at a morning safety meeting...I replied "No comment"...Seems my Boss, whos owned the business 25 yrs \& is fixed operations director of 2 dealerships as well...couldnt comprehend my reply?? So its confirmed...HE'S A COMPLETE JACK-ASS...not just Half-a Tard.

A sure sign summers done .... Detailing the owners boat for storage.

(This posting had a photograph of the boat owned by the owner of the West Coast Mazda on it).

A.P. on September 30 had the following posting on his own page: 
West coast detail and accessory is a fuckin joke...don't spend your money there as they are ... and are out to hose you... there are a bunch of greedy ... low life scumbags... wanna know how I really feel?????

I heard that Marco and [F. Y.] were seen fondling each others nut sack in the shop bathroom?? Any truth to that? That shop ripped off a bunch ppl I know.

All in humour, however, none of the stereo shit I bought there works, at all...Deck only plays store bought discs and subs are blown and amp is fried, again. The alpine stuff I bought from $A \& B$ works awesome tho.

I don't think theres enough room on Facebook to type all the bullshit out...gloves are off now....its game time

A.P. continued his posting with the following conversation with his girlfriend:

Girlfriend: Somethings just shouldn't be broadcasted on facebook, especially when you still work there.

A.P.: That's the whole point honey

On September 30, a former employee of West Coast Mazda had telephoned F.Y. to enquire "whether everything was okay" at the work having seen A.P's postings on Facebook. F.Y. accessed his account to check A.P.'s posting and brought it to the attention of J.C. J.C. subsequently reported these postings to the owners of West Coast Mazda who were very upset. On October 6, the Employer had separate investigatory meetings with J.T. and A.P. with their Union representatives. There were all provided with copies of the Facebook postings. J.T and A.P. were asked whether they made the inappropriate, critical, disrespectful and derogatory comments about management and owners of West Coast Mazda. They both denied making the postings. J.T. admitted to posting the picture of the owner's boat on his Facebook page and the Dexter comments but that it had nothing to do with the shop. A.P. denied posting on September 30 claiming that he had no more access to his Facebook account.

On October 7, J.T and A.P.’s employment were terminated for making disrespectful, damaging and derogatory comments on Facebook which the Employer found to be 
"inappropriate, insubordinate and creating a hostile work environment". The Employer noted J.T and A.P.'s denials at the investigation meeting saying that it compounded their wrongdoing.

The Union filed this complaint before the BCLRB stating that the Employer breached Sections 5, 6 and 9 of the Labour Relations Code. The Union also said that the terminations were made as an anti-union animus thereby committing unfair labour practices.

\section{Was there any anti-union animus in the termination?}

The main argument that the Union brought before the BCLRB was that the Employer failed to establish that the action taken against J.T and A.P. were motivated by anti-union animus. For example they said that the Employer started to build a file on J. T. on August 27 which was the day they were notified about the certification application. They argued that prior to this date F.Y. had access to J.T.'s Facebook account on which he had vented his angry feelings and no action was taken against him then. Also they mentioned that the Employer kept track of J.T.'s posting claiming that they were monitoring his union activity which to them was not necessary.

The Union also argued that the Employer ought to have called J.T. aside immediately they became aware of the Dexter's postings citing that they have been inconsistent in their reaction and previous treatment of homophobic comments in their workplace.

The Union also submitted the manner in which the Employer carried out its investigation about the conduct of J. T. and A. P. depicts anti-union animus as by not issuing a warning to the two of them meant that they were building up small infractions against them and also as a means of retaliating their support for the Union. They noted that the Employer started to build the file on J.T. and A.P. on September 24, the day that the certification application was received. 
Furthermore the Employer did not inform both J.T. and A.P. of their expectations of the use of Facebook which would have constituted a "corrective action" but went ahead to terminate them.

The Union argued that the Employer did not give any consideration to the fact raised by A. P. that he did not write the posting of September 30. It said that the Employer ought to have interviewed A.P.'s girlfriend to get some facts from her; they also failed to carry out any investigation about Internet usage at the work site until after his appointment had been terminated. The Union noted that even after the first set of postings was identified, the Employer still allowed them to carry on working meaning that "the employment relationship was not irreparably severed"6.

The Employer argued that the two employees' were terminated for proper cause noting that "there is a reasonable relationship between the misconduct in question and the penalty imposed" $"$. In proofing that A.P. did indeed write the posting of September 30, they argued that he was dishonest throughout the investigation and noted that he was angry for being sent home; which gave him ample time and sensitivity to make such comments.

\section{Was there any impact of social media policy?}

The Union acknowledged the seriousness of J.T. and A.P.'s verbal abuse on Facebook but argued that the Employer did not make its expectation clear to its employees regarding the use of this social media tools. In the case of J.T. the Employers asserted that the fact that he

\footnotetext{
${ }^{5}$ P. 13

${ }^{6}$ P. 14

${ }^{7}$ P. 8
} 
admitted to writing the post did not "negate proper cause" ${ }^{\prime 8}$ but the nature of the comments were “extremely damaging to the Employer's reputation and created a hostile and poisoned work environment" $"$. Relying on the decisions of the arbitrators in Chatham-Kent ${ }^{10}$ and Alberta $v$ Alberta Union of Provincial Employees ${ }^{11}$, the Employer argued that they don't have to have any rules in place for the appropriate use or posting on Facebook. Also the postings that referred to the supervisors were described as an aggravating factor noting the decision of the arbitrator in British Columbia Forest Products ${ }^{12}{ }^{i}$

The statements made on Facebook according to the employer were the same as making statements on the shop floor at the worksite. Relying on the decisions of the court in Leduc v $\operatorname{Roman}^{13}$, anyone with a Facebook account must not expect any privacy.

The Employer reiterated the fact that they had never had to deal with situations involving Facebook postings and so as a matter of fact there was a coincidence with the dates when they received the notification of certification and the date of the first posting brought to the attention of J.T.'s manager. They said they did not exercise any delay in investigating the misconduct. They also said that the fact that they did not react to J.T.'s first posting did not mean that the employment relationship has not been irreparably severed.

\footnotetext{
${ }^{8}$ P. 9

${ }^{9}$ P.9

${ }^{10} 159$ L.A.C. $\left(4^{\text {th }}\right) 321$

${ }^{11} 174$ L.A.C. $\left(4^{\text {th }}\right) 371$

${ }^{12}$ [1988] B.C.C.A.A.A. No. 154 ("BCFP”)

${ }^{13} 2009$ CanLII 6838 (Ont)
} 


\section{Decision of the British Columbia Labour Relations Board and Beyond}

The BCLRB examined the issue of whether the Employer - Lougheed Imports' action in terminating the employment of J. T. and A. P. was motivated by anti-union animus. The Board found no anti-union animus in the action. The Union in its argument relied on the Employer did not provide any of the factors listed by the Board in ETL Environmental Technology, BCLRB No. B195/93 ("ETL") to establish that it did not act upon anti-union animus.

The Board noted that the Facebook comments posted by J.T. and A.P. were "damaging comments about the Employer's business" having been posted to almost 100 or 377 people including employees. The comments were also described as "offensive, insulting and disrespectful" 14 about their supervisors and managers. The comments about the supervisors the Board said were "not similar conduct to the inappropriate comments made on the shop floor on a regular basis" $" 15$.

With respect to the manner in which the Employer carried out its investigation, the Board agreed with the Union that it was puzzling and suspicious that the Employer did not raise the Facebook postings with J.T. when they issued a disciplinary letter for disruptive and confrontational behaviour on September 24. It raises a suspicion because the Employer knew that J. T. was a strong supporter of the Union. Relying on the authority in Faryna $v$ Chorny ${ }^{16}$ to determine the credibility of the events leading to the termination of employment whether the Employer was monitoring the Facebook posting to build a file or whether they were unsure of

\footnotetext{
${ }^{14}$ P. 15

${ }^{15}$ P. 16 
how to proceed with the matter and terminated when it became intolerable ${ }^{17}$ ? The Board concluded that the Employer "was purposefully looking to terminate J. T. as they could have done so after the first posting that was brought to their attention on September 24. They also agreed that $\mathrm{J}$. T. was entitled to his opinion but not in terms of work related issues which could have consequences on an employment relationship. ${ }^{18}$

The Board also pointed out that the fact that the Employer did not take any disciplinary action after further insubordinate postings on September 27, 28 and 30 showed that they did not know how to handle this kind of situation. This explanation justified the preponderance of probabilities test in Faryna $v$ Chorny ${ }^{19}$.

On whether the Employer had proper cause to terminate their employment and whether the penalty was out of proportion, the Board agreed with the Employer. Referring to the fact laid out in its argument that the employment relationship was not irreparably severed, the Board stated that the comments made towards the supervisors were offensive and egregious so the action of the Employer was not out of proportion for the insubordination, it was the proper cause of action.

There is a trend of cases emerging as a result of dismissals for postings made on Facebook and other social media sites. Recently in Wasaya Airways LP v Air Line Pilots Association, International [2010] C.L.A.D No. 297, (Wyndels Grievance), Captain Wyndel's employment was terminated as a result of a posting he made on his Facebook page about his employers. The union claimed that he was wrongfully dismissed and that the discipline enforced

\footnotetext{
${ }^{17}$ P. 16

${ }^{18}$ P.17

19
} 
by the employers was too severe. The posting made by Captain Wyndel is as follows: "You know you fly in the north when ..." This comment was posted for his friends to read even though he added a disclaimer noting that the views and opinions were not those of the Facebook user and he subsequently removed it from his page. The arbitrator found that the comments could create potential harm to the reputation of the company and its ability to manage its business; his misconduct was a serious breach of the company's policies. However the discipline imposed by the company was found to be excessive.

The pace at which jurisprudence is developing in this area means that this issue needs to be taken more seriously.

\section{Does policy on social media use infringe on freedom of expression under the Charter of Rights and Freedoms?}

The section 2(b) provision of the Canadian Charter of Rights and Freedom was not raised by the British Columbia Labour Relations Board while reviewing this case. Section 2(b) of the Charter states that -

"Everyone has the following fundamental freedoms:

(b) freedom of thought, belief, opinion and expression, including freedom of the press and other media of communication;"

Freedom of expression is a fundamental right in the Canadian context and this is further guaranteed by the provisions of section 2(b) of the Charter. Two rationales have been identified for the guarantee of the freedom of expression; firstly the free flow of ideas is the best way to get the truth and secondly expression is seen as a means of individual autonomy, personal growth and self-realization (Sharpe, 2009). Cautiously noting that freedom of expression under the Charter is not absolute but has to be curtailed in some instances to respect and protect social 
values. So do we then raise this when considering the case before the British Columbia Labour Relations Board? The issue of freedom of expression was not raised by any of the parties in this case and the Board did not discuss it when it made a decision. Can J.T and A.P's postings on Facebook be considered as a means of individual autonomy, personal growth or even selfrealization?

The Supreme Court of Canada in interpreting the constitutional guarantee of the freedom of expression in a number of cases that have come before it has recommended that this right should be given a broad definition without any limitations. In Ross v. New Brunswick School District No. 15 the La Forest, J. noted that section 2(b) of the Charter must be given a broad and purposive interpretation; while the purpose of the constitutional guarantee is to permit free expression in order to promote truth, political and social participation, and self-fulfillment. The Supreme Court has consistently held that freedom of expression is not restricted to views shared or accepted by the majority but meant to protect the views of the minority no matter how unpopular they may be. McLaughlin $\mathrm{J}$ in $R v$ Zundel clearly stated that:

"The purpose of the guarantee is to permit free expression to the end of promoting truth, political or social participation, and self-fulfillment. That purpose extends to the protection of minority beliefs which the majority regards as wrong or false: Irwin Toy, supra, at p. 968. Tests of free expression frequently involve a contest between the majoritarian view of what is true or right and an unpopular minority view. As Holmes J. stated over sixty years ago, the fact that the particular content of a person's speech might "excite popular prejudice" is no reason to deny it protection for "if there is any principle of the Constitution that more imperatively calls for attachment than any other it is the principle of free thought -- not free thought for those who 
agree with us but freedom for the thought that we hate": United States v. Schwimmer, 279 U.S. 644 (1929), at pp. 654-55."

While all these justifications have been used solely for print media publications, this argument has been used by other courts lately for issues relating to postings on social $\mathrm{n}$ media websites such as Facebook. In Pridgen $v$ University of Calgary after establishing that the Charter applies to University policies, the court held that the University had infringed on the freedom of expression rights of the students as provided by section 2(b). In this case, two University of Calgary undergraduates were placed on probation for committing non-academic misconducts for the postings they wrote about one of their professors on Facebook. The students sued the University claiming that it had infringed on their guarantee to freedom of expression according to the provisions of section 2(b) of the Charter of Rights and Freedoms. The court noted that the Facebook postings by the Applicants have expressive content and convey meaning. It further acknowledged that the Facebook wall did serve as a forum for discussion and that even though some of the comments made by the students about their professor were unfavourable and reflected immaturity, the discipline measures adopted by the Review Committee of the University of Calgary were considered to be excessive and should be set aside. The following is the posting made on Facebook by Pridgen and his friends about Professor Mitra:

"Hey fellow LWSO. homees .. So I am quite sure Mitra is NO LONGER TEACHING ANY COURSES WITH THE U OF C !!!!! Remember when she told us she was a long-term professor? Well actually she was only sessional and picked up our class at the last moment because another prof wasn't able to do it ... lucky us. Well anyways I think we should all congratulate ourselves for leaving a Mitra-free legacy for future L.S.W.O. students!” 
One then wonders whether this can be applied in the case of Facebook postings in the workplace where there are no policies and expectations by the employer. Can one then assume that postings made by J.T and A.P. about their supervisors and employer were just a free expression of their view for social participation and self-fulfillment?

The fact is that the postings were made accessible to millions of users on Facebook and depending on the privacy settings, these postings can be viewed by everybody and a lot of harm can be done. The University of Calgary in its letter to the students noted that the conduct of the students has "caused unwarranted professional and personal injury to Prof. Mitra".

Using the interpretation of La Forest J. in Ross v New Brunswick School District No. 15, that in "...cases where expression is communicated in a physically violent manner..."; one can argue that the language used by J.T. and A.P in their Facebook postings were violent and damaging to their supervisors and employers even though they were made outside the work place and after hours. The British Columbia Labour Relations Board described these comments as "offensive and egregrious" expressing contempt and ridiculous. Even though the scope of constitutional freedom has been described as very broad, it is not enough to express one's opinion to ridicule others. A.P's posting was directed at discouraging people from patronizing his employers; this is just not offensive and egregrious but also mischievous. The Ross' case and the Lougheed Import case have a number of similarities as the comments by these parties were all made outside the work place and publicly. Ross, a teacher made anti-Semitic remarks which were published and distributed to the public; he also made television appearances. Attis a parent whose children attended school in the district where Ross taught filed a human right complaint against the school board under section 5 of the Human Rights Act. Attis also suggested that this was religious discrimination as the school Board did not discipline Ross for his action which 
discriminated against another religion; also he suggested that the Board condoned Ross' outside classroom activities.

In the case of the University of Calgary students, their comments were seen as a form of criticism which may assist future students in course selection and also as a form of feedback for the department. I will like to argue that the students comments is damaging to the professional reputation of Prof. Mitra even though they were exercising their freedom of expression rights. The postings were capable of destroying Prof. Mitra's reputation as an academic, whatever the student's grievance against her style or method of teaching; she also has constitutional protection under section 2(b) of the Charter.

The nature of all these postings on social media tools shows that these tools allow people to "vent true feelings" and they tend to be aggressive online. This is what J.T and A.P. used Facebook to communicate to all those who had access to their pages. Organizations and employers still need to set up policies that will help employees know how to handle communication on social networking sites given the rate at which they are being used. In the next part of this case review I have taken a critical look at the Ontario College of Teachers Professional Advisory on the use of electronic communication and social media. This document is a guideline written by this regulatory body as a result of the impact of electronic communication and social media among its members. This document from my own opinion will help teachers know where to draw the line when using any of these means of communication whether at work or outside. It also offers a kind of limited protection for them as long as they follow the guidelines. This is the kind of proactive initiative that should be taken by not just regulatory bodies but employers and labour unions as a means of creating a safe workplace in the era of social media. 


\section{A response to the Ontario College of Teachers Professional Advisory: Use of Electronic Communication and Social Media}

Given the position of authority and trust that teachers hold in the society and also because of the demographics of their students, the Ontario College of Teachers is one of the first regulatory bodies to come up with this kind of policy document. The College had over the years observed a number of challenges posed by the use of social media which have become new options for instruction hence the need to put policies in place to address them. According to the Registrar of the College; “....the College has seen an increase in the number of complaints made that involve some form of misuse of electronic communication and social media. Some involve students and some do not. Some involve a lapse in judgment on the part of the member, which while unintentional, had serious consequences for the member. Others involved conduct on the part of the member that was egregious, warranting findings by the College's Discipline Committee of professional misconduct and in some cases, warranting criminal convictions by a court" 20

The Ontario College of Teachers in writing up this Professional Advisory is carrying out one of its objectives as a regulatory body according to s. 3(1)(7) of the Ontario College of Teachers Act, 1996 - To establish and enforce professional standards and ethical standards applicable to members of the College. This document serves as an administrative tool to help discourage improper behaviour while using electronic communication and social media. Also it has a duty to serve and protect the public interest.

\footnotetext{
${ }^{20}$ Electronic Communication and Social Media - the New Frontiers "There's (Quite Probably) an App for That" ...or a Professional Advisory. Toronto: Ontario College of Teachers, 2011. p. 35
} 
The guidelines according to the Registrar of the College were also developed from the results of a survey of conducted for its members on the usage of the Internet; Table 1 below summarizes some of the responses received. The table shows that teachers use the Internet for researching for work, looking for classroom resources, staying current on education trends, networking as well as using it to access social networking sites such as Facebook, YouTube, Twitter and MySpace; blogging, and reading newspapers. And in fact, Facebook is highly used by teachers as they spend an average of 3.6 hours on it compared to the other sites.

\section{Table 1 Internet Use by Members of the Ontario College 21}

\begin{tabular}{|l|l|}
\hline Activity & Usage( Hours) \\
\hline Online Research in connection with work & 4.8 \\
\hline Looking for classroom resources & 3.7 \\
\hline Finding Lesson Plans & 3.5 \\
\hline Staying current on education trends & 3.4 \\
\hline Networking & 2.8 \\
\hline Managing class or school website & 2.1 \\
\hline Blogging about teaching & 1.3 \\
\hline Reading newspapers & $3.3-3.5$ \\
\hline Facebook & 3.6 \\
\hline YouTube & 2.5 \\
\hline Twitter & 1.2 \\
\hline MySpace & 1.1 \\
\hline
\end{tabular}

In the digital age where technology and social networking sites have introduced another method of instruction, it is inevitable for instructors and teacher to look for ideas for teaching and instructing their students'- members of the "digital tribe". The Professional Advisory clearly acknowledges the innovation that the Internet has imposed on the teaching profession and is

\footnotetext{
${ }^{21}$ The figures used in this table were reproduced from the "Electronic Communication and Social Media - the New Frontiers “There's (Quite Probably) an App for That" ...or a Professional Advisory”. Toronto: Ontario College of Teachers, 2011. p. 35
} 
especially mindful of the fact that these sites were not created specifically for educational purposes and may likely expose members to risks. ${ }^{22}$

The Professional Advisory document addresses the following four areas and provides clear guidelines:

1. New Frontiers in Teaching and Learning

2. Private vs. Professional

3. Criminal and Civil Law Implications

4. Disciplinary Implications

In the first section, the Professional Advisory acknowledges the purpose of electronic communication and social media as effective tools for teachers, students and parents and guardians. The guideline prescribed now leaves it to members to know and respect proper professional boundaries with students, even when students initiate electronic interaction" ${ }^{23}$. It noted that these media were not originally designed for "educational purposes" clearly letting members know that a sense of professionalism is expected from them. This guideline also implies that there is a level of risk involved in the use of these sites and warns teachers to take precautions in using them. Teachers are expected to notify parents/guardians before using social networks for classroom activities as well as give them access to these pages. ${ }^{24}$

The second guideline distinguishes between the private and professional life of a teacher. It declares that teachers should maintain sound judgment, due care and a sense of professionalism at all times in their personal and professional lives. The teacher's off-duty activity regardless of whether it is directly related to teaching is relevant to their suitability to

\footnotetext{
${ }^{22}$ Professional Advisory: Use of Electronic Communication and Social Media p. 3

${ }^{23}$ Ibid p. 1

${ }^{24}$ Ibid p. 6
} 
teach; making reference to the Supreme Court of Canada's ruling in $R v$ Audet $^{25}$, Ross $v$ New Brunswick School District No. $15^{26}$ and Toronto (City) Board of Education v OSSTF. ${ }^{27}$ The guideline states that teachers should maintain a professional persona when in communication with students electronically and it should be done at appropriate times of the day using educational platforms such as a school webpage and not a personal one. Similarly they are required to decline student-initiated friend requests and they are not to issue friend requests to students.

In the third guideline which focuses on professional vulnerability, teachers are reminded that "social media encourage casual dialogue" and tends to lead to informal communication. As a result, they are asked to avoid private texts, phone numbers, personal email contacts and photos of a personal nature from students. ${ }^{28}$ This guideline emphasizes the fact that online communications are visible to the public and they are not anonymous and can be archived even if deleted by the users.

The College in guideline four gives its members a warning on the criminal and civil implications of inappropriate use of electronic communication and social media. The guideline outlines examples of actions and resulting charges such as defamation, disclosing confidential information about the school, students and colleagues, posting others work without proper attribution, breach of court-ordered publication ban, harassment, inciting hatred, distribution of child pornography and luring. It noted that this medium can be used to gather evidence for

\footnotetext{
${ }^{25}$ [1996] 2 S.C.R. 171

${ }^{26}[1996] 1$ S.C.R. 825

${ }^{27}[1997] 1$ S.C.R. 487

${ }^{28}$ Professional Advisory: Use of Electronic Communication and Social Media.p.6
} 
criminal and civil proceedings; the findings of which can be used at the College's disciplinary hearings. There has been a disturbing number of criminal cases involving teachers in the past decade especially computer related crimes. I cannot provide the statistics at this point but it will be the subject of another work. However the social media aspect is an emerging area with a lot of interesting cases coming up in the courts all over the world.

As a regulatory body, the College has the onus to discipline it members and the fifth guideline states that the misuse of social media and electronic whether intentional or inadvertent could have serious disciplinary consequences ${ }^{29}$. It noted some behaviours that have been used to discipline members such as:

- inappropriate electronic communication with students, colleagues, parents/guardians and others

- $\quad$ sending graphic sexual materials electronically to students

- using school equipment to access, view or download pornography, including child pornography

- luring students and non-students via the Internet, as defined by the Criminal Code". 30

The Professional Advisory goes further to establish guidelines in understanding privacy concerns of teachers, students and members of the public in general. It urges members to manage the privacy and security settings of their social media accounts and to check them as frequently as possible since they change. Privacy settings for contents and photos are to be set appropriately and require that students should not be allowed to view or post among others.

\footnotetext{
${ }^{29}$ Professional Advisory: Use of Electronic Communication and Social Media P.5

${ }^{30}$ Ibid P.5
} 
No doubt these guidelines constitute a form of clarity to members of the Ontario College of Teachers on the use of electronic communication and social media especially when teachers have to use them as part of their instructional tools. In justifying the need for the need for a professional advisory, the College noted that "A professional advisory (a "policy statement", or "code" or "guideline") is typically issued in response to a demonstrated need for clarity or precision with respect to either the conduct of the professional or the regulator's discretion in overseeing that conduct. It may address imprecision in a regulator's enabling statute, regulations or other applicable legislation or rules. It may speak to a nuance that is not addressed in statute or other rules. It may be deemed necessary once a court case has been decided that may have some bearing on how the regulator carries out its activities and how professionals carry out their professions $^{31}$." In addition to being a regulator, the reality of the level of contact that teachers have with the demographics of the students makes it necessary to have such a document. The College said that "...many members are in contact with children and teens on a daily basis - in their professional capacities as for instance, teachers, principals and vice-principals, or as coaches or mentors...",32

Also many of the teachers joining the profession bring a range of skills and experience using these tools; this was noted by the Registrar that "...young teachers may be more vulnerable and may not realize when the professional boundary line has been crossed. They are well versed in the use of social media and used to the informality typically associated with the used of social

\footnotetext{
${ }^{31}$ Electronic Communication and Social Media - the New Frontiers "There's (Quite Probably) an App for That" ...or a Professional Advisory”. Toronto: Ontario College of Teachers, 2011. p. 31

${ }^{32}$ Ibid p. 33
} 
(sic) could lead them to cross the professional line". ${ }^{33}$ These guidelines should provide a means of overcoming some of these challenges to members.

\section{What are the risks of Using Social Media}

Having reviewed the facts of the Lougheed case and the contents of the Professional Advisory issued by the Ontario College of Teachers, there is no doubt that the use of social media poses a lot of risks, a fact which is still not being taken seriously. Social media has come of age and will continue to grow exponentially as new technology emerges. Bennett and Collie (2011) observed that using social networking sites comes with a number of risks such as privacy and confidentiality. They suggested that companies should also establish employee policies to deal with some of the risks of social networking sites. These policies should cover issues such as privacy, confidentiality, copyright infringement, defamation and comments by employees on the business and activities of the employer.

Privacy - The nature of social media tools such as Facebook, Twitter, and LinkedIn is for friends and acquaintances to share information, media in the form of picture, video etc. These forms of information dissemination are so personal that it almost becomes impossible for people to know when to draw the line of communication. And moreover a lot of corporations and organizations are now using these media for networking; hiring, promotion and advertisement purposes which means that information going through these channels are no longer personal but corporate. It also implies that the boundaries between personal and professional lives tend to be blurred as noted in the Ontario College of Teachers Professional Advisory and also in a number of literatures on this subject. This then means that a lot of privacy issues and concerns will and have been occurring. In Leduc v Roman, one of the cases that British Columbia Labour Relations

\footnotetext{
${ }^{33}$ Ibid p. 35
} 
Board cited in its decision, the court in this case ruled that users of Facebook should not expect any privacy when it comes to the documents they have posted on this medium. Similarly Semitsu (2011) in a review of Facebook privacy policies in the context of the United States noted that users of lack reasonable expectation of privacy when using this media. He noted that government agencies are using contents of social networking sites to gather incriminating evidence against citizens. And in Canada, the Office of the Privacy Commissioner in 2009 conducted an investigation into the privacy policies and practices of Facebook after it received complaints that they were not in compliance with Canadian privacy laws. Facebook agreed to address these concerns but this does not prevent the privacy risks that exist when using social media.

Defamation - Postings on social media are full of personal expressions such as what J.T and A.P. posted on their walls and also what the University of Calgary students posted about Professor Mitra. The contents of these posts will qualify as defamation if the affected parties decide to take on a civil litigation. Hence while employers are now using social media for different things, there needs to be some proper coordination as to what is to be posted and the type of language and expression that is used.

Copyright - The subject of copyright will arise and pose a risk when pictures, videos etc are posted on social media and they go 'viral' or are used without the permission of the owner or when pictures are tagged. The subject of ownership and intellectual property will always arise with social media.

\section{The Future of Social Media in the Workplace}

Even before the Ontario College of Teachers Professional Advisory was released, there have been a lot of debates across the globe on the use and impact of social media in the 
workplace and also among professionals like medical practitioners, legal practitioners, nurses etc. While acknowledging the ubiquitous nature of social media, Lowe and Yeung (2011) noted that Canada does not have any specific laws focused on regulating social media sites; as result it means that lawyers have to be creative in dealing with issues that arise with these issues. They said that as a way of integrating social media in the workplace, businesses need to prepare to react to the ubiquitous nature of this media. They suggested preventative measures such as using legal counsel to prepare general policies regulating employees conduct when using these media during business hours.

Similarly Moulton (2010) noted that the use of social networking sites has created more legal issues. Having a social media policy in place will reduce the risks and complexities of legal problems for employers. This policy should comply with privacy laws and should respect workplace policies and confidentiality agreements. I am assuming that workplace policies being suggested by in this case will include bargaining unit contracts and agreements in the case of a unionized environment.

In the United States it has been observed that the use of social networking websites has outpaced established legal practices and that bar associations need to fill the gaps by coming up with opinions and best practice guidelines. Bennett (2009) noted that the ABA Model Rules of Professional Conduct does not directly address all the ethics concerns associated with social networking. Bennett suggested that the legal profession should adapt legal ethics rules to social networking because interactions between attorneys, clients and communities of social network users can become quite complicated. Perhaps that is why in the Florida Judicial Ethics Advisory Committee's opinion of November 9, 2009 to judges on the use of social network sites; they are 
asked not add lawyers who may appear before them as friends or permit those lawyers to add them as friends. This kind of policy is firm and draws the line as to the kind of expectation from members of the judiciary in that jurisdiction; so that whoever violates this kind of policy has nothing to fall back on.

Vinson (2010) in her article also affirmed that boundaries between personal and professional lives tend to be blurred when members of the legal community are using social networking sites because they now provide new ways of doing professional tasks. She called for the education awareness and need for guidelines to illustrate the risks involved so as to reduce adverse consequences as well as empower and help them adapt to this new media. Vinson makes recommendations for written guidelines to educate members of the legal community.

In a critique of how school boards in the United States have been restricting the use of social networking sites by educators Nidiffer (2010) reviewed a number of cases that have come before the different levels of courts in the United States and observed that there have been a lot of inconsistencies by the courts on placing restrictions on what educators write or say on these sites. Nidiffer offers suggestions on setting acceptable use policies and guidelines for educators' use of social networking sites.

While some employers are afraid of the risks posed by social media and are reluctant to embrace it and agree that it is now a way of life, suffice it to say that these tools have come to stay and its use will need to be properly addressed by regulatory bodies, employers, unions etc. 


\section{Recommendations}

A lot of employers have information technology policies in place for their employees but this should not be confused with social media policies. Social media policies should include guidelines and expectations of the employer for the appropriate use of social media in the work place and beyond. Examples of these can be found in Appendix I (Ontario College of Teachers Professional Advisory). Waggott (2010) suggested that a social media policy should cover not just company blogs and social media accounts; they should cover appropriate use of employee's personal accounts. He further noted that these policies need to clearly state that use applies to both work computers and any personal devices. These guidelines and policies must come with these explanations when being implemented since many employers are also using social media for branding, advertisement, public relations and marketing. For example almost all the food chains and clothing stores in Canada like President's Choice, Loblaws, Fortinos, Old Navy, Sears, $H \&$ M and The Bay have a social media presence where they advertise and promote their products and services. Similarly a lot of public institutions like universities and colleges have social media pages. It is the employees who write up the information that goes up on these sites. Guidelines on the appropriate use of these tools must be available to the employees. Even in the wake of the phone hacking scandal that has rocked News International recently; in an analysis of the governance issues that this case has exposed, Garrett (2011) identified that the company (News International) needs to review its email and document retention policies on a regular basis since email was one of the means of communication that sparked the scandal.

Suffice it to say then that these days policies for using social media is highly imperative for employers in the public and private sector and also regulatory bodies with the rate at which technology keeps changing. These policies will be constituted by legal experts, human resources, 
union representatives so as to cover all grounds such as the risks and benefits to both employees and employers. Waggott (2011) observed that it is important for employees and employers to understand how social media use fits into traditional employment and labour concepts. And furthermore, he noted that social media policies need to be integrated into companies existing policies on protection of privacy and confidential information, workplace safety, discipline and conduct in the workplace; there is a need for a delicate balance between restricting employees' right to freedom of expression and protecting the employer. A policy for the use of social media will also serve as a safe workplace document which is always very helpful in a diversified environment.

A social media policy will take into consideration the fact that technology keeps changing and so it will be all encompassing to address all future and emerging trends. Each organization will be prepared to keep abreast of latest developments and include them in their policy.

Employers should provide a mandatory orientation and training for employees on the impact of social media in today's work place. This will be a part of the implementation process when guidelines and policies have been drafted. Contents of such training will include enlightenment on how to write comments on these sites, the nature of the language and content to be used when making comments about the work place.

\section{CONCLUSION}

This paper has reviewed the Lougheed case where the decision of the British Columbia Labour Relations Board was that the termination of two employees as a result of postings that they made on a social networking site (Facebook) was not motivated by anti union animus; instead their comments were found to be egregious and damaging to their employer's business. 
The BCLRB in this case did not address whether the postings made were a demonstration of the employees Charter Rights. In my opinion and despite the courts' decision in Pridgen v University of Calgary that postings made by students about a university professor on Facebook was a way of demonstrating their freedom of expression under the Canadian Charter of Rights and Freedoms; guidelines and policies are necessary to address the risks involved in using social media .

I noted that the employers in the Lougheed case admitted that they have not been exposed to any incidents about the use of Facebook by an employee which is a clear signal that employers need to have such policies in place. The paper makes some recommendations for employers having reviewed some of the risks involved in the use of social media. I also reviewed the recently released guideline by the Ontario College of Teachers (Appendix I). 


\section{REFERENCES}

Bennett, J., Owers, et al 2010. “Workplace Impact of Social Networking.” Property Management 28(3):138-148.

Bennett, C., \& Collie, D. 2010. "The Risks of Using Social Networking Sites.” The Lawyers Weekly 30(5): 10-13.

Bennett, S. 2009-2010. "Ethics of Lawyer Social Networking." Albany Law Review, 73(1):113137.

Carpay, J., \& Burton-Williams, D. 2008. The Right to Offend: A Canadian Constitutional Principle. Calgary: Canadian Constitution Foundation.

Clemens, J., Karabegović, A., and Veldhuis, N. 2005. Explaining Canada's High Unionization Rates. Vancouver: Fraser Institute.

Dine, P. 2011. Economic Watch: Loss of industry, employer tactics undercut unions. The Washington Times, 5 January, p. 1.

Foley, S. (2010,). Tesco's US operation accused of bullying staff; European multinationals are exploiting America's weak labour laws to suppress unions, claims report by Human Rights Watch. The Independent (London), 2 September, p. 2.

Fudge, J. 2004. "Labour is not a Commodity": The Supreme Court of Canada and the Freedom of Association." Saskatchewan Law Review 67:425-452.

Garrett, A. (2011, July 22). News Corporation Governance Issues [Blog Post]. Retrieved from http://internationalcorpgov.blogspot.com/

Gindin, S. (2007,). Unions cannot afford more Magna-type deals. Toronto Star, 26 October, AA.8.

Glasbeek, H. 1987. "Labour Relations Policy and Law as a Mechanisms of Adjustment." Osgoode Hall Law Journal 25(1):179-237.

Gray, C. 2009-2010. The Too Friendly Judge? Social Networks and The Bench. Judicature 93(6): 236-237.

Gray, J. (2011,). Think before you tweet. The Globe and Mail, 25 May, B. 9.

Hart, J. 2010. Criminal Infiltration of Financial Institutions: A Penetration Test Case Study. Journal of Money Laundering Control , 55-65.

Hepple, B. 2003. Rights at work. Geneva: International Labour Organization. 
Kirbyson, G. 2011. “One poorly judged tweet can trash image.” The Bottom Line 27(9):1-2. Lowe, J., \& Yeung, S. 2011. "Integrating Social Media in the Workplace." The Lawyers Weekly 30(25):1-3.

McCallum, M. 1996. "Labour and the Liberal State:Regulating the Employment Relationship, 1867 - 1920.” Manitoba Law Journal 23:574-593.

Moon, R. J. 2000. The Constitutional Protection of Freedom of Expression. Toronto: University of Toronto Press.

Moulton, D. 2010. "Social Media Policies Can Reduce Risk.” The Lawyers Weekly 30(23):1-2.

Niddifer, P. (2010). "Tinkering with Restrictions on Educator Speech: Can School Boards Restrict What Educators Say on Social Networking Sites?" University of Dayton Law Review 36(1-2):115-142.

North, E. 2009-2010. "Facebook Isn't Your Space Anymore: Discovery of Social Networking Websites." University of Kansas Law Review 58(5):1279-1309.

Overholt, C. \& Pitcher, E. 2010. "Social Media: Opportunities and Limitations in the Workplace FMC Law." Accessed 25 July 2011.

http://www.fmclaw.com/upload/en/publications/2010/Social_Media_Opportunities_Limitations In_The_Workplace.pdf

Pothier, D. 2002. "Twenty Years of Labour Law and the Charter.” Osgoode Hall L.J. 40:369400.

Saint-Cyr, Yosie. 2010. Employees Fired for Facebook Comments [Blog Post]. Accessed 11 November 2011.Retrieved from http://www.slaw.ca/2010/11/11/employees-fired-for-facebookcomments/

Sarra, J. 2003. "Recent Developments in Judicial Review of Arbitration Decisions, Dancing the Two-Step in British Columbia." U. B. C. L. Rev. 36:311-337.

Semitsu, J. 2011. "From Facebook to Mug Shot: How the Dearth of Social Networking Privacy rights revolutionized online government surveillance." Pace L. Rev. 31(1):291-381.

Sharpe, R. 2009. The Charter of Rights and Freedoms. Toronto: Irwin Law.

Slinn, S. 2008. "No Right (to Organize) Without a Remedy: Evidence and Consequences of the Failure to Provide Compensatory Remedies for Unfair Labour Practices in British Columbia." McGill L. J. 53(4):687-737. 
Sumner, L. 2004. The Hateful and the Obscene: Studies in the Limits of Free Expression. Toronto: University of Toronto Press.

Thomas, L. 2010. "Social Networking in the Workplace: Are Private Employers Prepared to Comply with Discovery Requests for Posts and Tweets Comments." SMU Law Review 63(4): 1373-1402.

Tibbetts, J. 2009. Wal-Mart Case Goes to Court. Leader Post, 21 January, D2.

Waggott, G. 2011. "Creating social media policies for the workplace”. The Lawyers Weekly 31(10):10-13.

"B.C. board upholds layoff of Mexican farm workers; Labour body rules employer was unaware of union organizing and did not engage in unfair practices." 2008. Toronto Star, 10 October. A. 29. Accessed 15 January 2011

http://ezproxy.library.yorku.ca/login?url=http://proquest.umi.com.ezproxy.library.yorku.ca/pqdw $\underline{\text { eb}}$ did=1571017371\&sid=1\&Fmt=3\&clientId=5220\&RQT=309\&VName=PQD

Vinson, K. (2010). "The Blurred Boundaries of Social Networking in the Legal Field: Just "Face" It". The University of Memphis Law Review 41(2):355-411. 
APPENDIX I - Ontario College of Teachers Professional Advisory: Use of Electronic Communication and Social Media

http://www.oct.ca/publications/PDF/Prof Adv Soc Media EN.pdf 